\title{
Heteroanionic Materials Based on Copper clusters, Bisphosphonates and Polyoxometalates: Magnetic Properties and Comparative Electrocatalytic NOx Reduction Studies
}

Olivier Oms, Shu Yang, William Salomon, Jérôme Marrot, Anne Dolbecq, Eric Rivière, Antoine Bonnefont, Laurent Ruhlmann, and Pierre Mialane

Supporting Information 
Figure SI1. Representation of the two POM units which coexist in $\mathbf{S b W}_{\mathbf{9}} \mathbf{C u A l e}$ of formula a) $\left[\mathrm{Sb}_{2} \mathrm{~W}_{18} \mathrm{O}_{66} \mathrm{Cu}_{3}\left(\mathrm{H}_{2} \mathrm{O}\right)_{3}\right]^{12-}$ (POM1) and b) $\left[\mathrm{Sb}_{2} \mathrm{~W}_{18} \mathrm{O}_{66} \mathrm{Cu}_{3}\left(\mathrm{H}_{2} \mathrm{O}\right)_{2} \mathrm{Cl}\right]^{13-}(\mathrm{POM} 2)$; c) 1D structure with the alernance of POM1 and POM2 units; blue octahedra, $\mathrm{WO}_{6}$; purple spheres, $\mathrm{Sb}$; green spheres, $\mathrm{Cu}$; orange spheres, $\mathrm{P}$; black spheres, $\mathrm{C}$; blue spheres, $\mathrm{N}$; red spheres, $\mathrm{O}$; bright green sphere, $\mathrm{Cl}$.

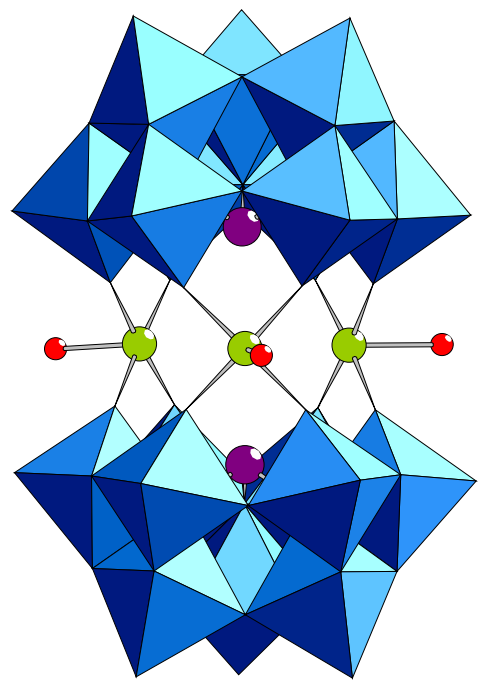

a)

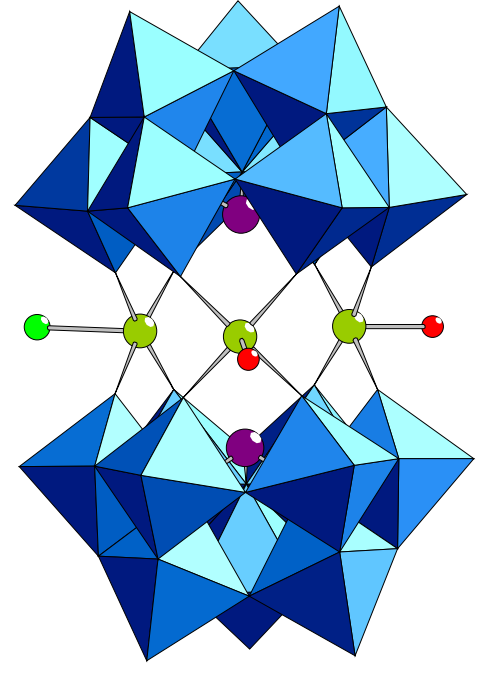

b)

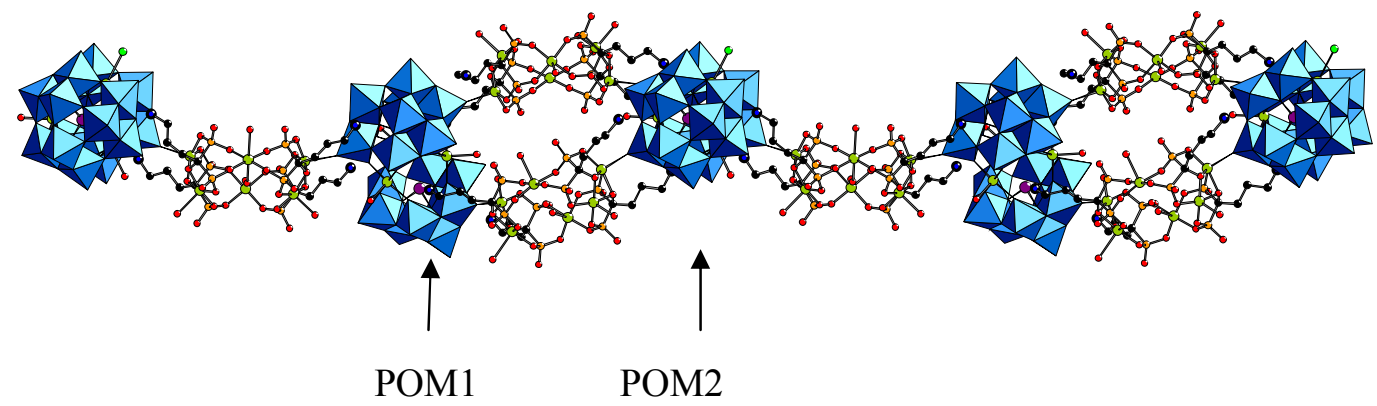

c) ${ }^{\cdots}$ 
Table SI1. Electrocatalytic efficiency compared by using the kinetic current $\left(\mathrm{J}_{\text {kinetic }}\left(\mathrm{NO}_{3^{-}}\right)\right.$or $\mathrm{J}_{\text {kinetic }}$ $\left(\mathrm{HNO}_{2} / \mathrm{NO}_{2}^{-}\right)$in $\mu \mathrm{A} \cdot \mathrm{cm}^{-2}$ at different values of the excess parameter $\gamma\left(\gamma=C_{\mathrm{NO}_{3}-}^{0} / \mathrm{C}_{\mathrm{POM}}^{0}\right)$ or $\left.\gamma=\mathrm{CHNO}_{2} / \mathrm{NO}_{2}-/ \mathrm{C}_{\mathrm{POM}}^{0}\right)$.

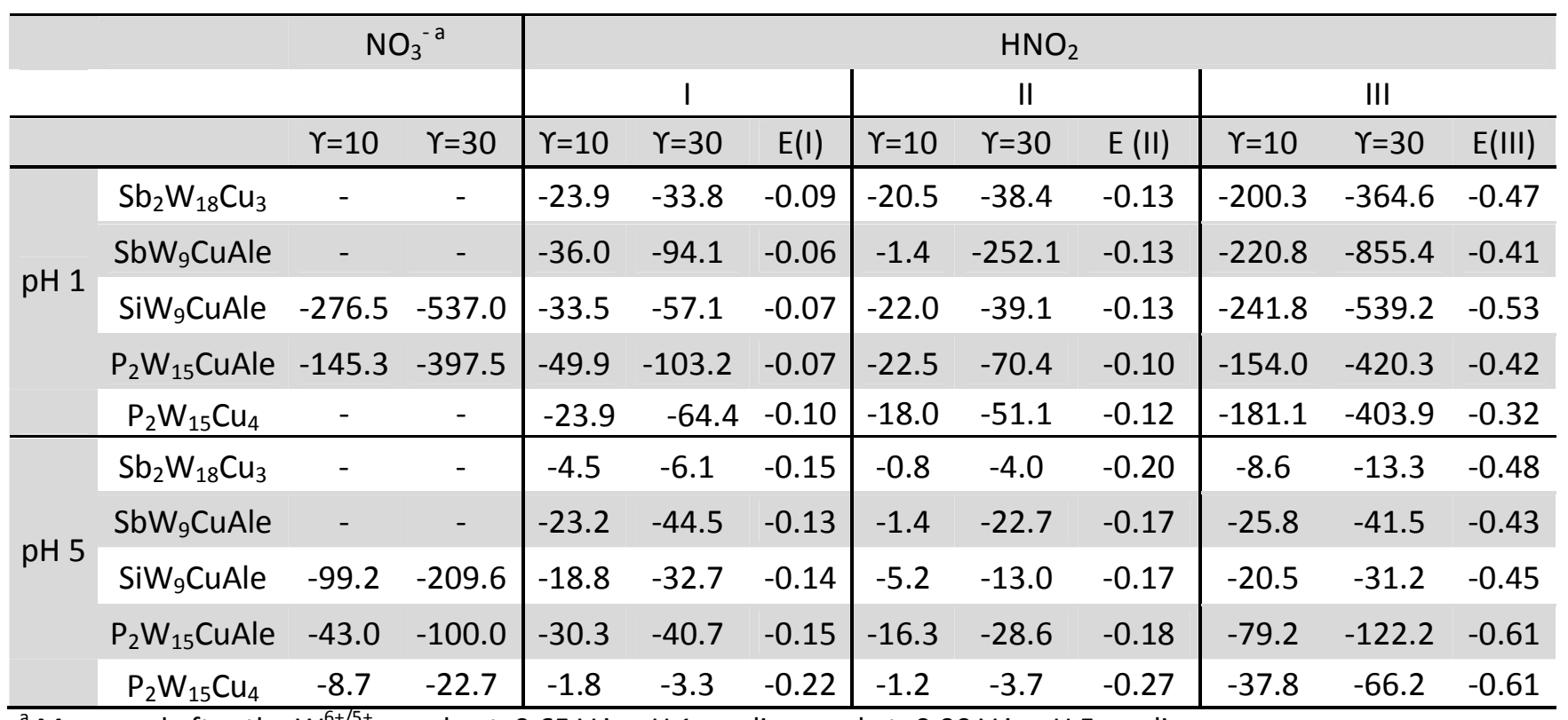

${ }^{\mathrm{a}}$ Measured after the $\mathrm{W}^{6+/ 5+}$ couple at $-0.65 \mathrm{~V}$ in $\mathrm{pH} 1$ medium and at $-0.90 \mathrm{~V}$ in $\mathrm{pH} 5$ medium.

Figure SI2. A) Cyclic voltammograms of $0.1 \mathrm{mM} \mathrm{Sb}_{\mathbf{2}} \mathbf{W}_{\mathbf{1 8}} \mathrm{Cu}_{\mathbf{3}}$ in a $\mathrm{pH} 5$ buffer solution, v= 2 mV.s ${ }^{-1}$. B) Variation of scan rates (from inner to outer curve) are 10, 20, 30, 40, 50, 60, 70, 80, 90 , and $100 \mathrm{mV} . \mathrm{s}^{-1}$. The potential reversal is fixed after the $\mathrm{Cu}^{2+} / \mathrm{Cu}^{+}$redox process. (Inset) Variations of the cathodic peak current intensities as a function of the square root of the scan rate. ${ }^{*}$ Reoxidation peak of the deposited $\mathrm{Cu}^{0}$ on electrode surface.
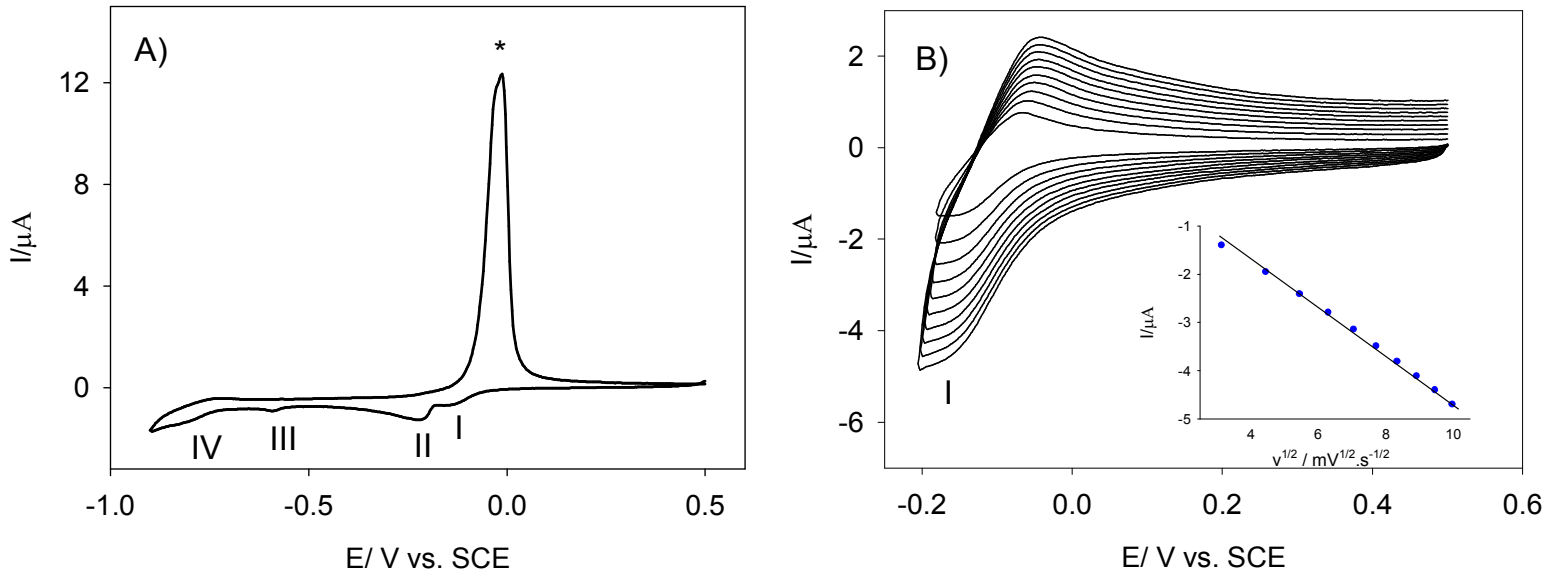
Figure SI3. A) Cyclic voltammograms of $0.1 \mathrm{mM} \mathrm{SbW}_{9} \mathrm{CuAle}$ in a $\mathrm{pH} 5$ buffer solution, $v=2$ $\mathrm{mV} . \mathrm{s}^{-1}$. B) Variation of scan rates (from inner to outer curve) are 10, 20, 30, 40, 50, 60, 70, 80, 90 , and $100 \mathrm{mV} . \mathrm{s}^{-1}$. The potential reversal is fixed after the $\mathrm{Cu}^{2+} / \mathrm{Cu}^{+}$redox process. (Inset) Variations of the cathodic peak current intensities as a function of the square root of the scan rate. * Reoxidation peak of the deposited $\mathrm{Cu}^{0}$ on electrode surface.
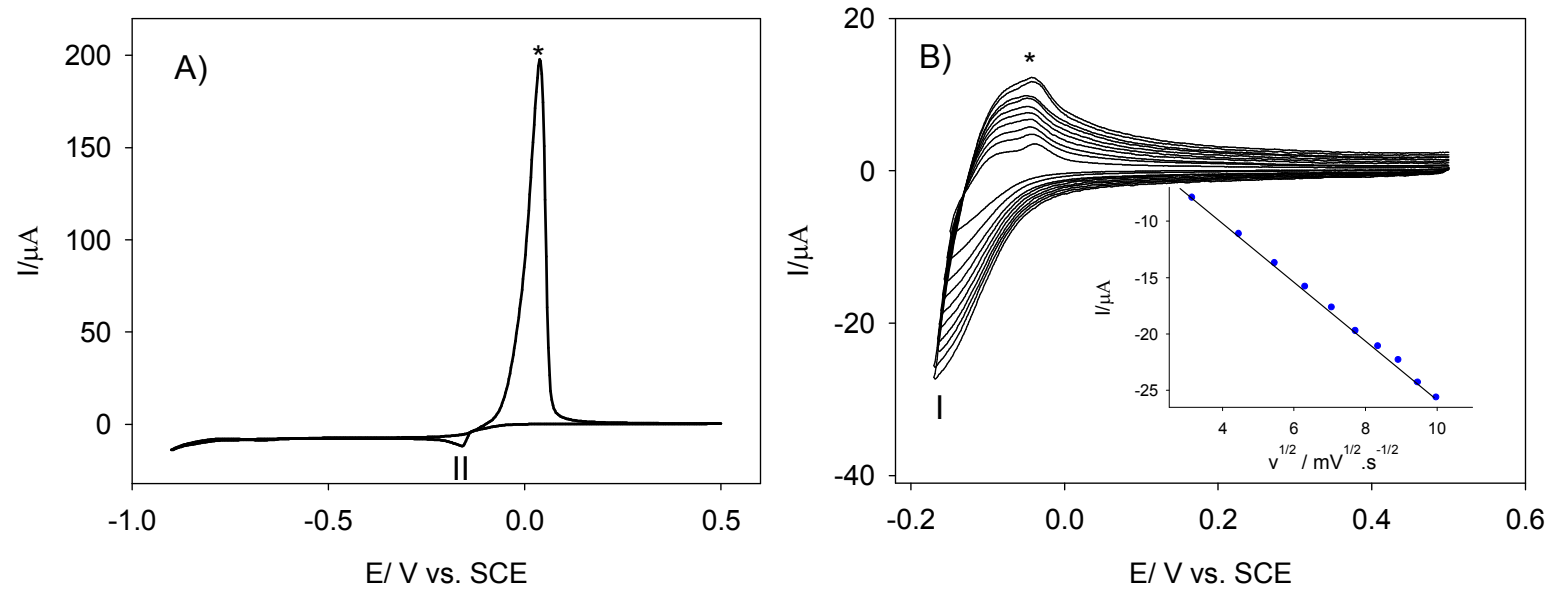

Figure SI4. A) Cyclic voltammograms of $0.1 \mathrm{mM} \mathrm{SiW}_{9} \mathrm{CuAle}$ in a $\mathrm{pH} 5$ buffer solution, v= 2 $\mathrm{mV} . \mathrm{s}^{-1}$. B) Variation of scan rates (from inner to outer curve) are 10, 20, 30, 40, 50, 60, 70, 80, 90 , and $100 \mathrm{mV} \mathrm{s}^{-1}$. The potential reversal is fixed after the $\mathrm{Cu}^{2+} / \mathrm{Cu}^{+}$redox process. (Inset) Variations of the cathodic peak current intensities as a function of the square root of the scan rate. ${ }^{*}$ Reoxidation peak of the deposited $\mathrm{Cu}^{0}$ on electrode surface
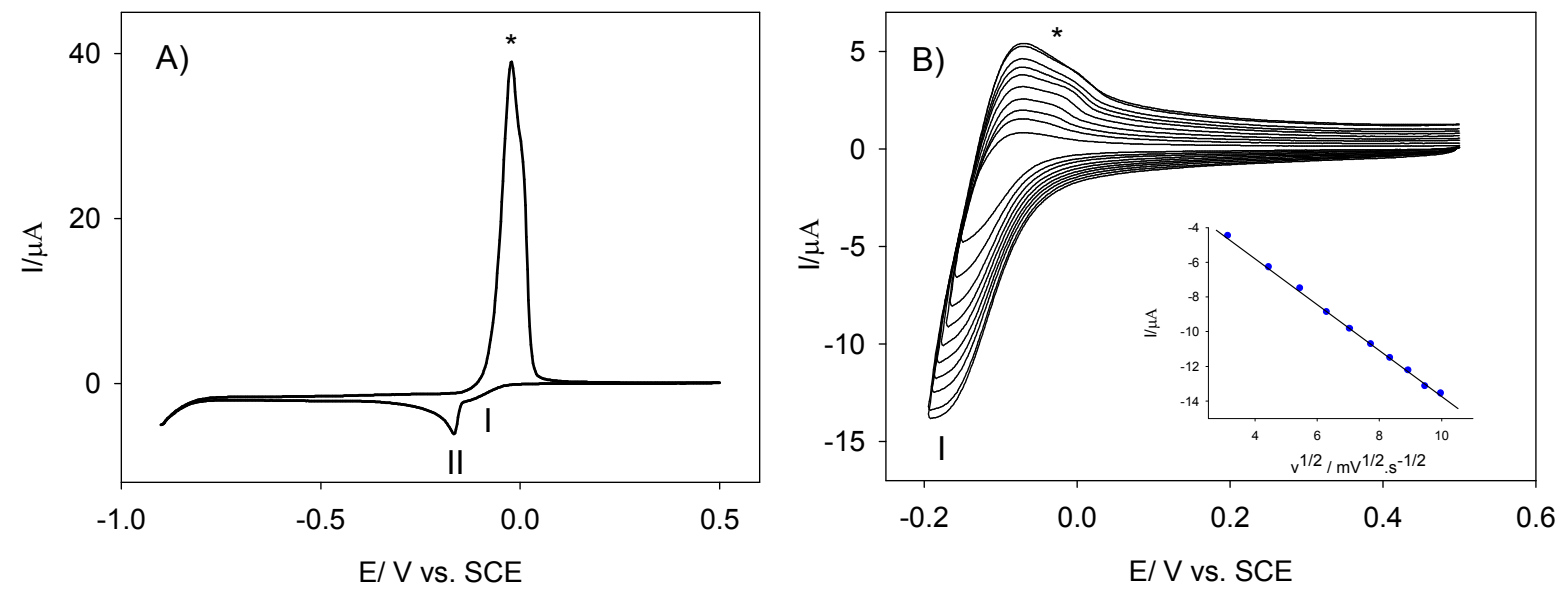
Figure SI5. Cyclic voltammograms of $0.1 \mathrm{mM}_{\mathbf{2}} \mathbf{W}_{\mathbf{1 5}} \mathbf{C u}_{4}$ in a $\mathrm{pH} 5$ buffer solution. $\mathrm{v}=2 \mathrm{mV} . \mathrm{s}^{-1}$

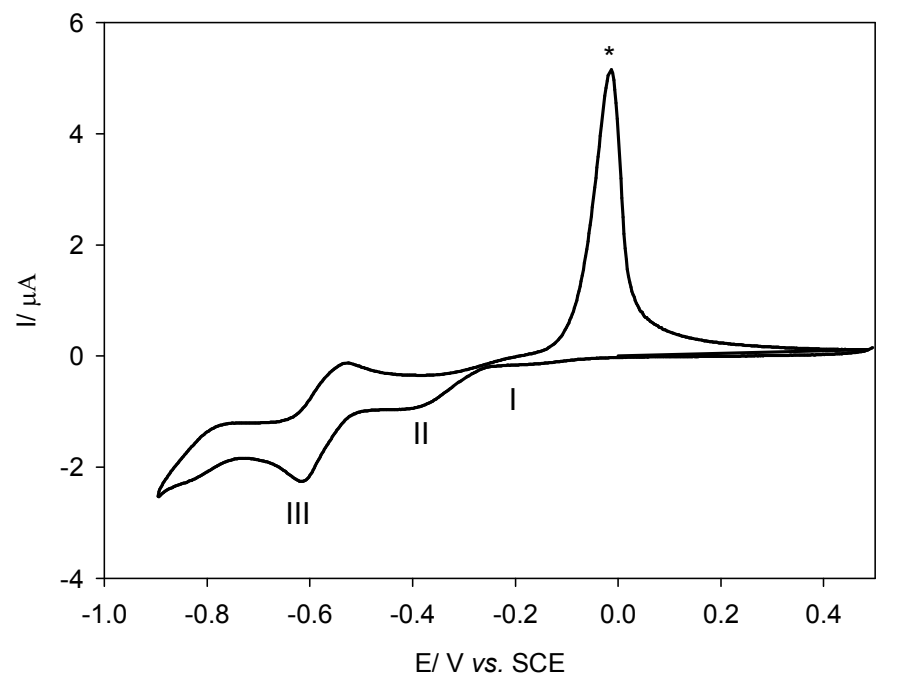

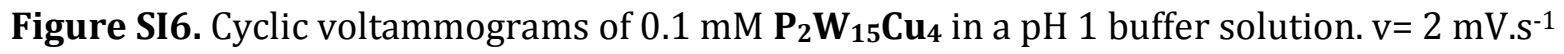

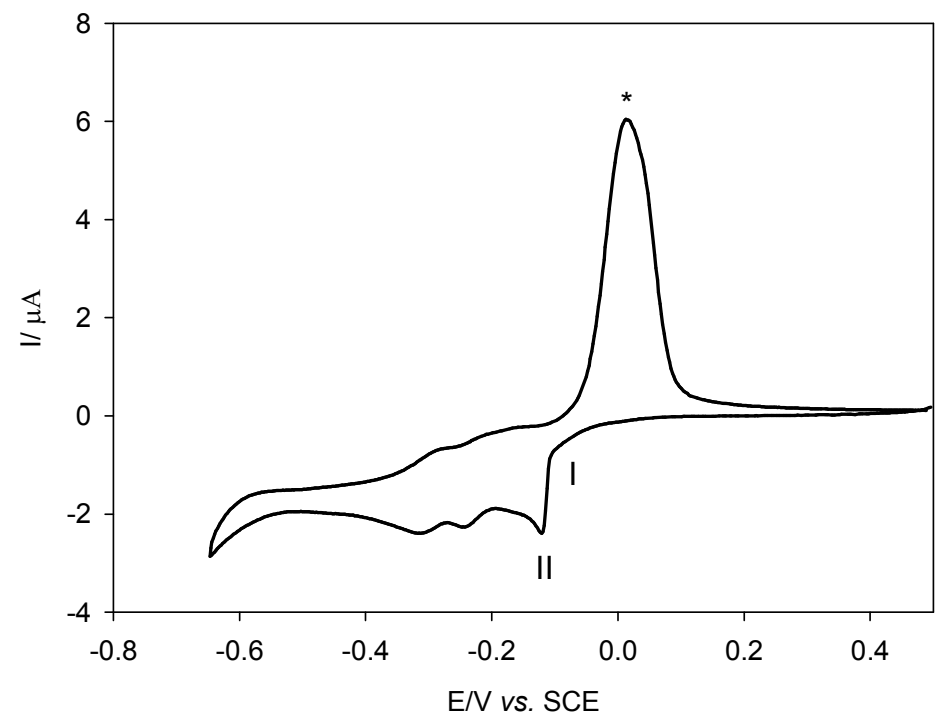


Figure SI7. Cyclic voltammograms of $0.1 \mathrm{mM} \mathbf{P}_{2} \mathbf{W}_{\mathbf{1 5}} \mathbf{C u A l e}$ in a $\mathrm{pH} 1$ buffer solution. $\mathrm{v}=2 \mathrm{mV} . \mathrm{s}^{-}$ 1.

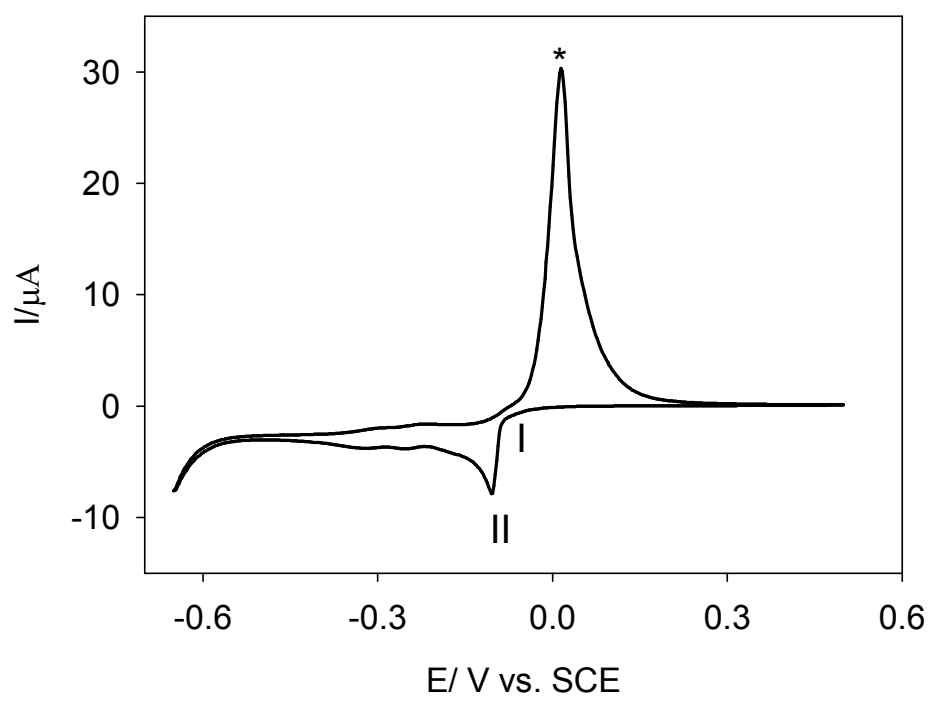

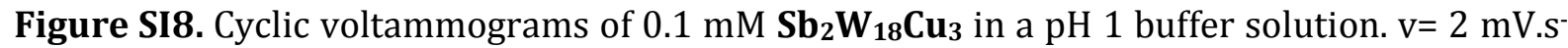
1.

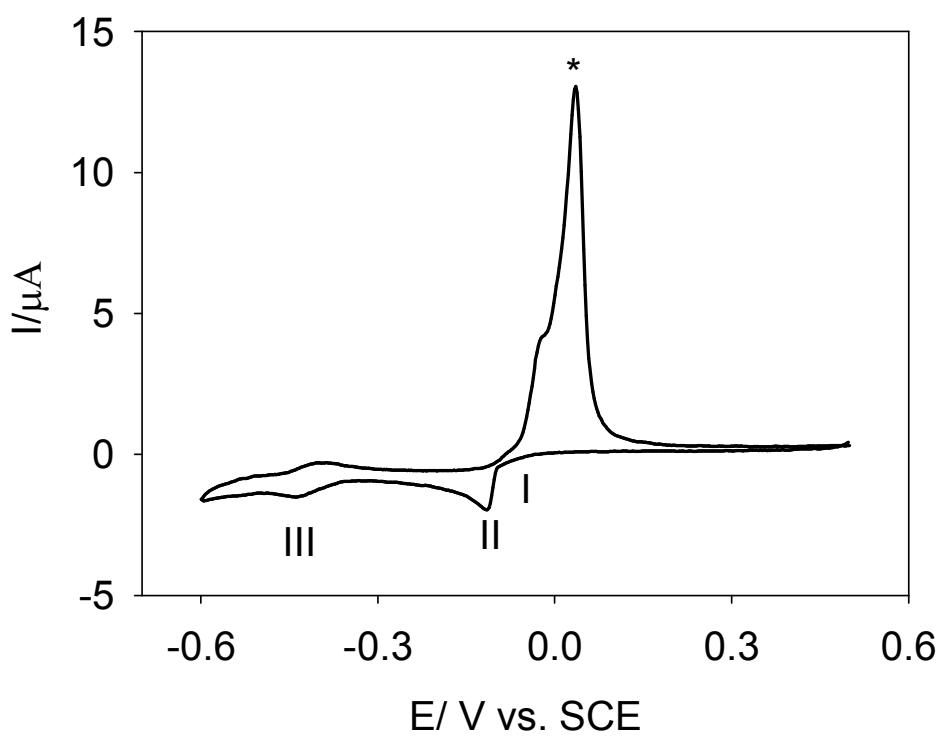


Figure SI9. Cyclic voltammograms of $0.1 \mathrm{mM} \mathrm{SbW}$ CuAle in a pH 1 buffer solution. v= 2 mV.s ${ }^{-1}$.

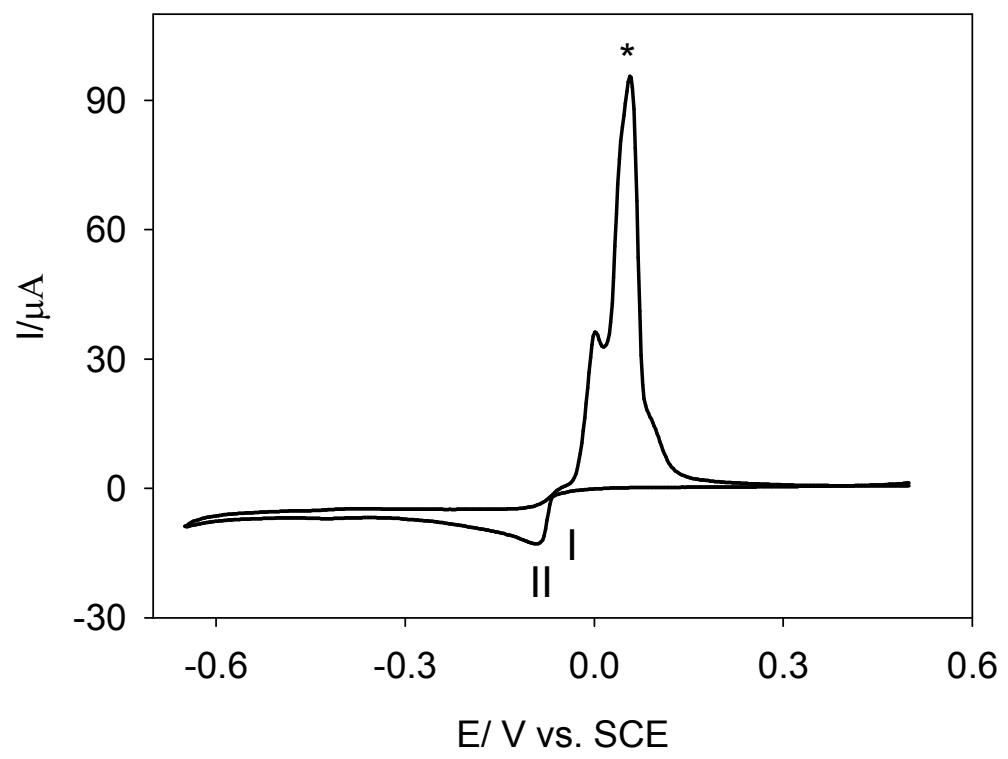

Figure SI10. Cyclic voltammograms of $0.1 \mathrm{mM} \mathrm{SiW}$ CuAle in a pH 1 buffer solution. v= 2 mV.s ${ }^{-1}$.

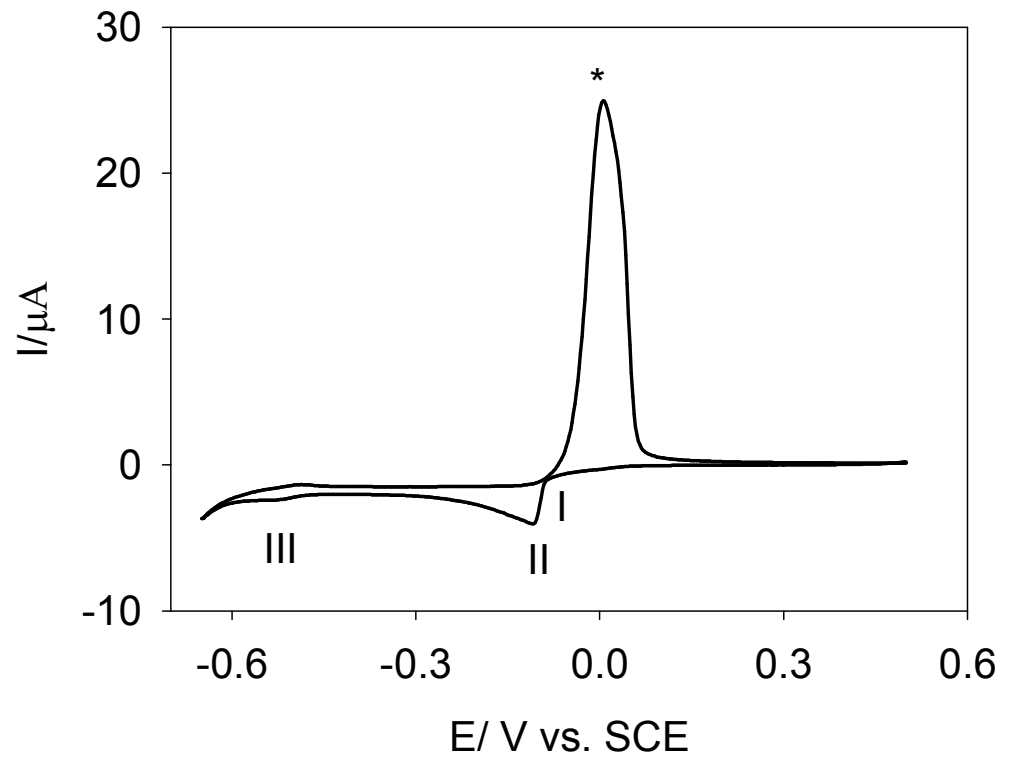


Figure SI11. Electrocatalysis of $\mathrm{NO}_{3}-(1 \mathrm{mM})$ reduction in the presence of $0.1 \mathrm{mM}$ $\mathbf{P}_{2} \mathbf{W}_{15} \mathbf{C u A l e}$ (blue dotted line) compared to $0.1 \mathrm{mM} \mathbf{P}_{\mathbf{2}} \mathbf{W}_{\mathbf{1 5}} \mathbf{C u A l e}$ (red dotted line) and $1 \mathrm{mM}$ of $\mathrm{NO}_{3}{ }^{-}$(black full line) in a pH 5 medium. $\mathrm{v}=2 \mathrm{mV} . \mathrm{s}^{-1}$
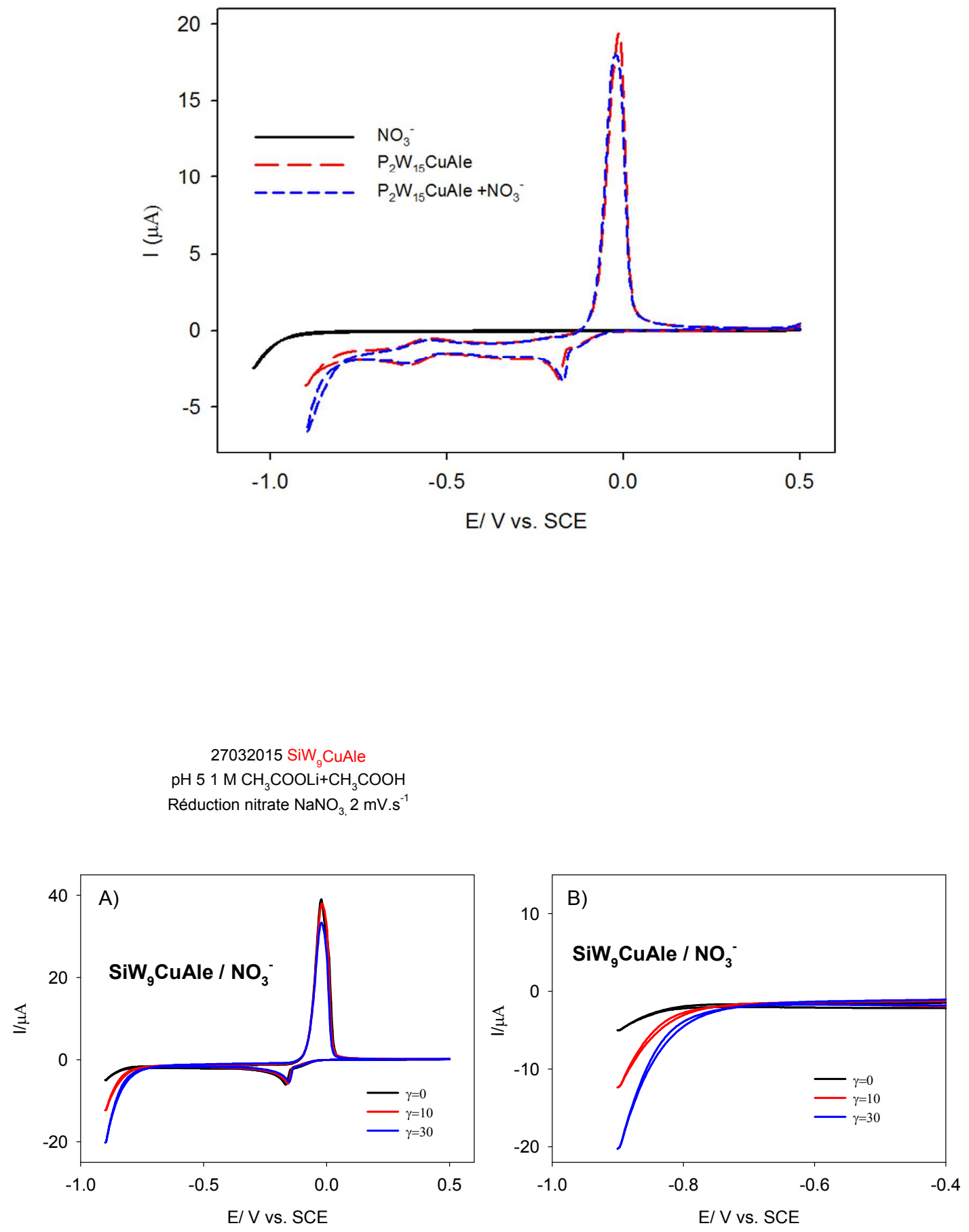
Figure SI13. A) Electrocatalysis of $\mathrm{NO}_{3}{ }^{-}$reduction in the presence of $0.1 \mathrm{mM} \mathbf{P}_{2} \mathbf{W}_{15} \mathbf{C u}_{4}$ in a pH 5 medium. $v=2$ mV.s ${ }^{-1}$. B) Magnification of A) to highlight the reduction of nitrate ions.
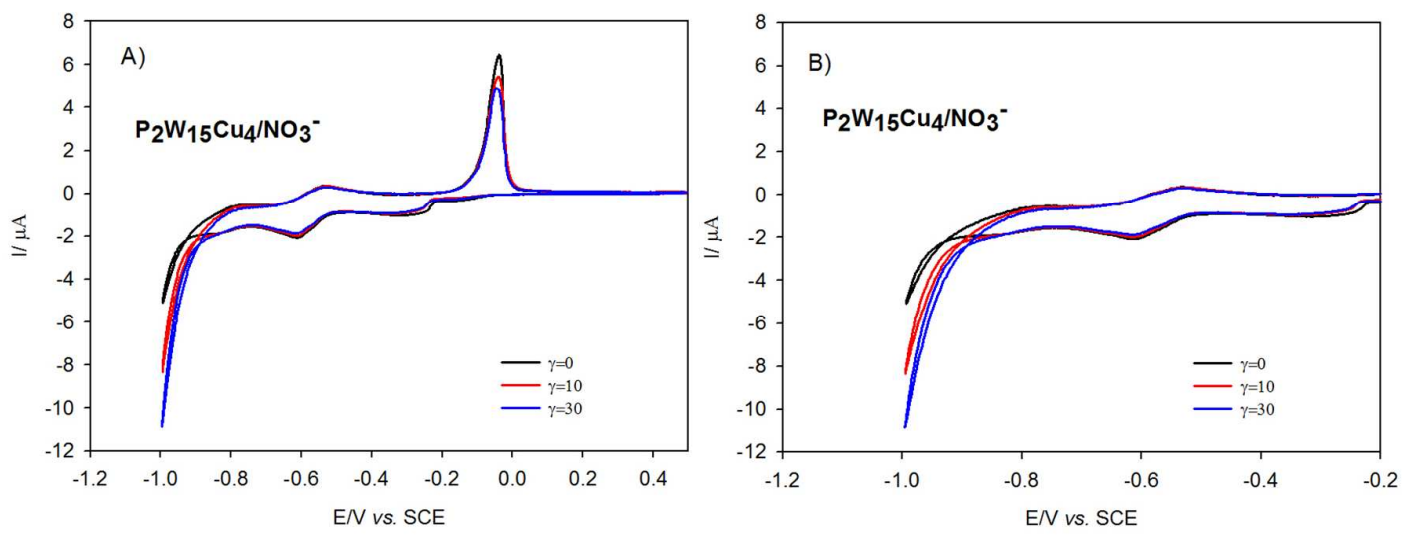

Figure SI14. A) Electrocatalysis of $\mathrm{NO}_{3}-$ reduction in the presence of $0.1 \mathrm{mM} \mathrm{P}_{\mathbf{2}} \mathbf{W}_{15} \mathrm{Cu}_{4}$ in a $\mathrm{pH} 1$ medium. $\mathrm{v}=2 \mathrm{mV} . \mathrm{s}^{-1}$. B) Magnification of A) to highlight the reduction of nitrate ions.
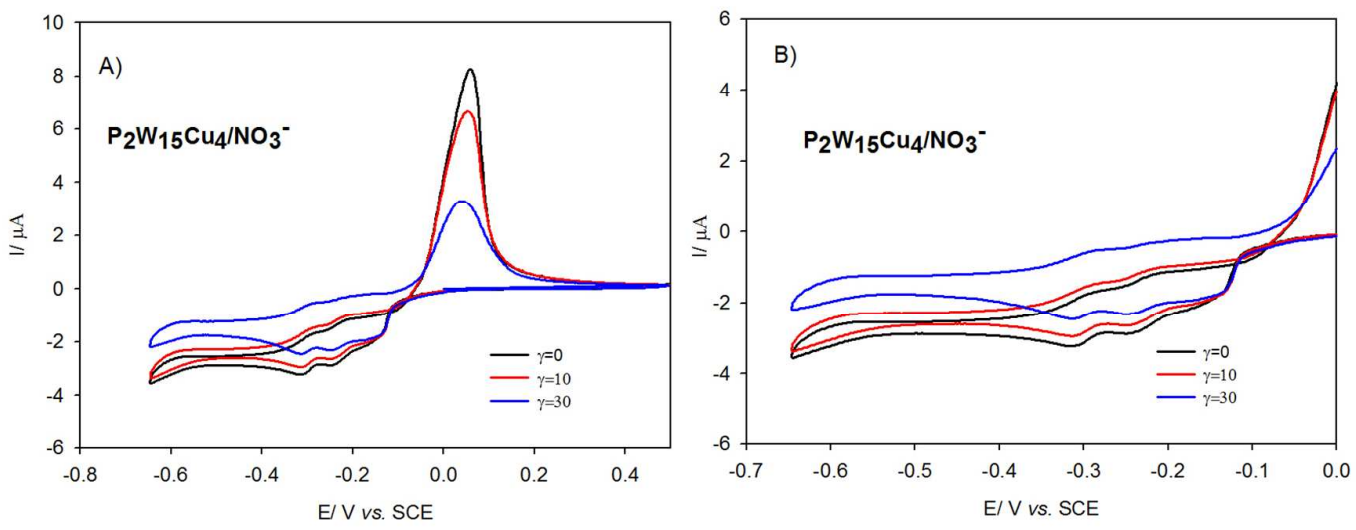
Figure SI15. A) Electrocatalysis of $\mathrm{NO}_{3}{ }^{-}$reduction in the presence of $0.1 \mathrm{mM} \mathrm{Sb_{2 }} \mathbf{W}_{18} \mathrm{Cu}_{3}$ in a $\mathrm{pH} 5$ medium. $\mathrm{v}=2 \mathrm{mV} . \mathrm{s}^{-1}$. B) Magnification of A) to highlight the reduction of nitrate ions.
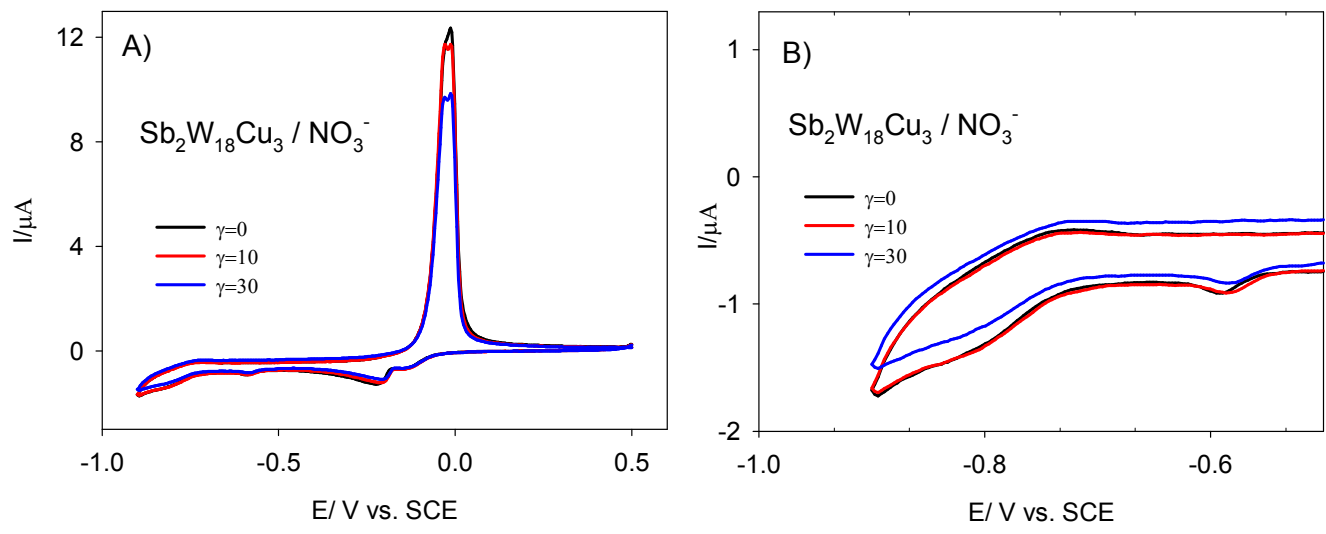

Figure SI16. A) Electrocatalysis of $\mathrm{NO}_{3}{ }^{-}$reduction in the presence of $0.1 \mathrm{mM} \mathbf{S b W}_{9} \mathrm{CuAle}$ in a pH 5 medium. $\mathrm{v}=2 \mathrm{mV} . \mathrm{s}^{-1}$. B) Magnification of A) to highlight the reduction of nitrate ions.
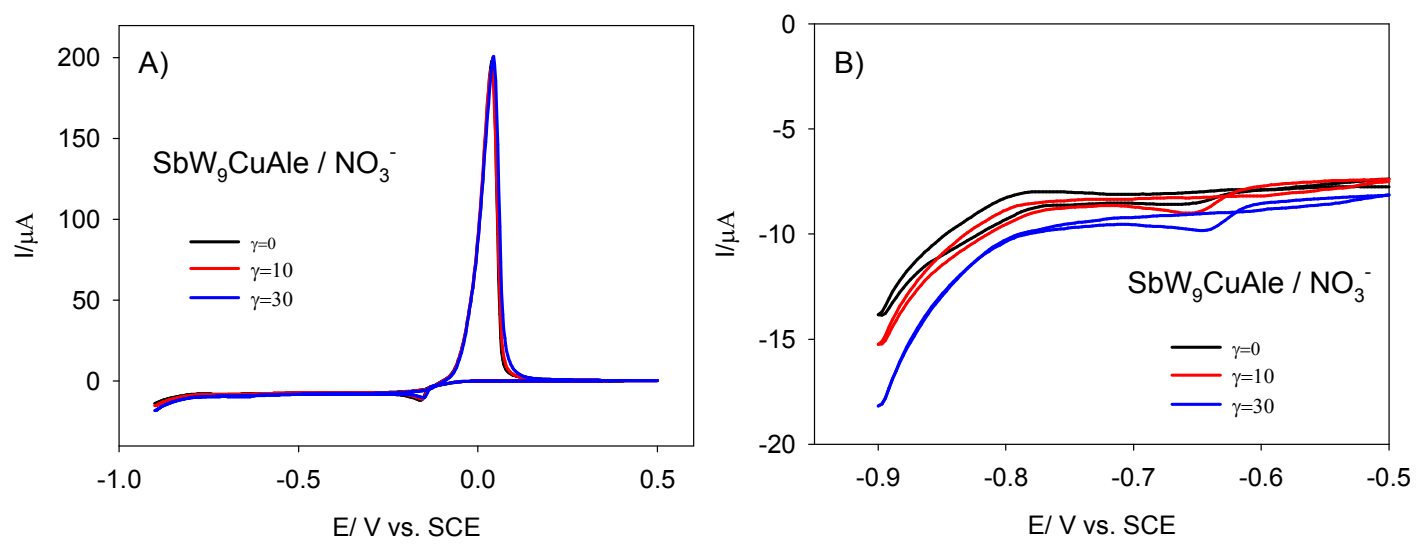
Figure SI17. A) Electrocatalysis of $\mathrm{NO}_{3}^{-}$reduction in the presence of $0.1 \mathrm{mM} \mathbf{P}_{2} \mathbf{W}_{15} \mathrm{CuAle}$ in a pH 1 medium. v= $2 \mathrm{mV} \cdot \mathrm{s}^{-1}$. B) Magnification of A) to highlight the reduction of nitrate ions. * Reoxidation peak of the deposited $\mathrm{Cu}^{0}$ on electrode surface.
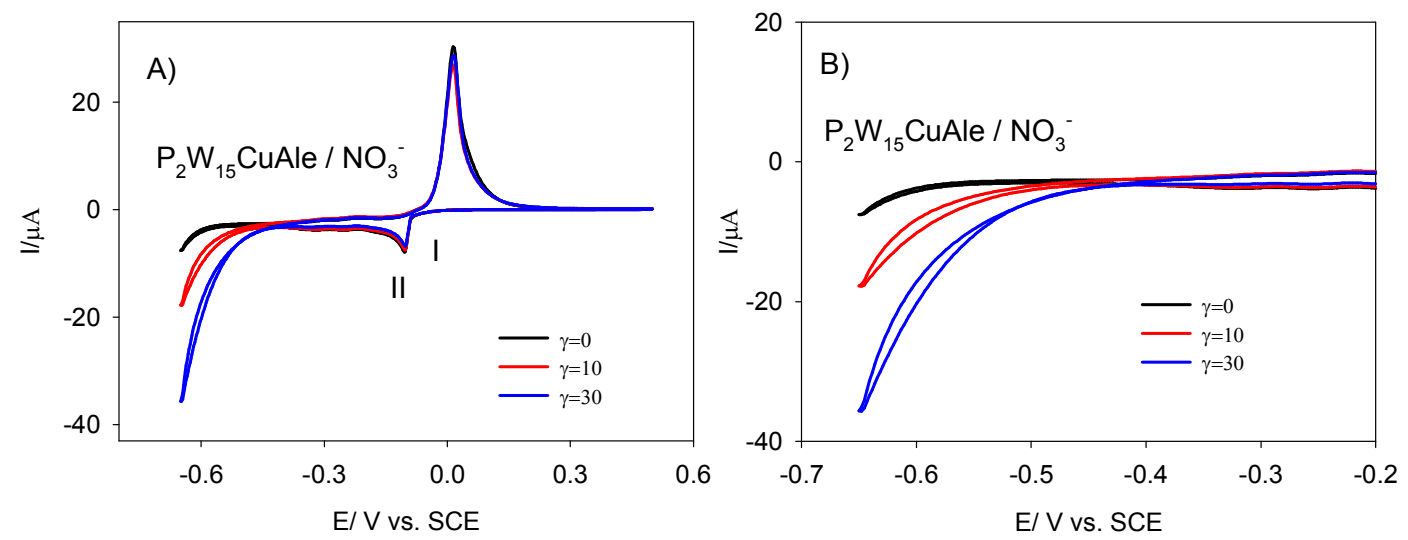

Figure SI18. A) Electrocatalysis of $\mathrm{NO}_{3}-$ reduction in the presence of $0.1 \mathrm{mM} \mathrm{SiW}_{9} \mathrm{CuAle}$ in a pH 1 medium. v=2 mV.s ${ }^{-1}$. B) Magnification of A) to highlight the reduction of nitrate ions.
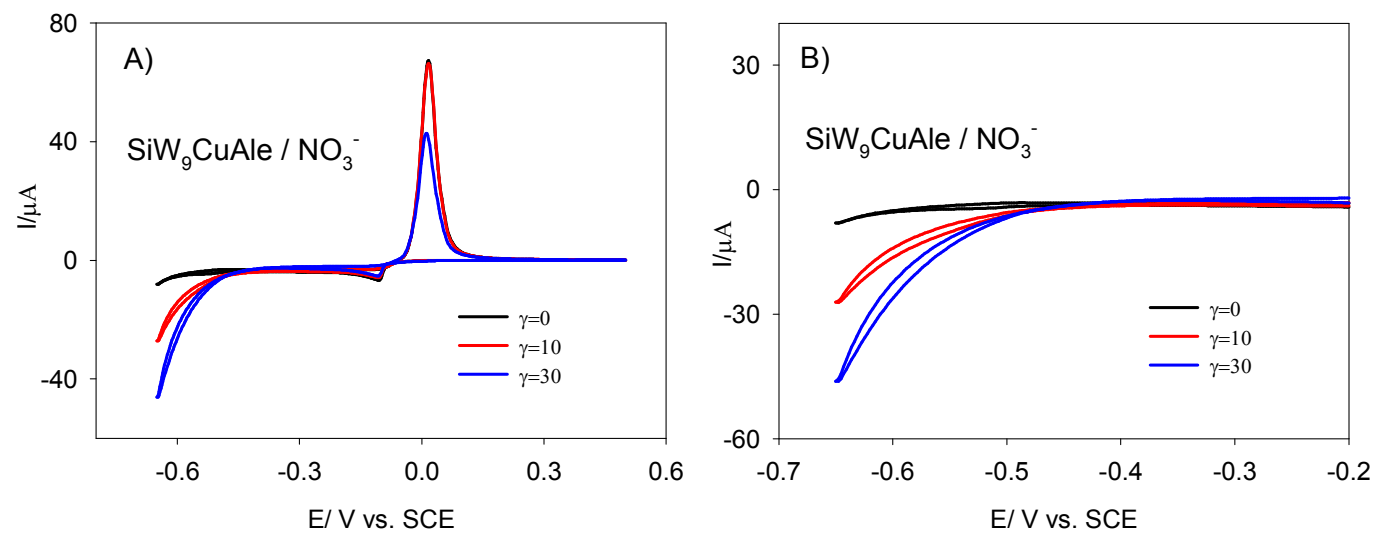
Figure SI19. A) Electrocatalysis of $\mathrm{NO}_{3}{ }^{-}$reduction in the presence of $0.1 \mathrm{mM} \mathrm{Sb_{2 }} \mathbf{W}_{18} \mathrm{Cu}_{3}$ in a pH 1 medium. v=2 mV.s ${ }^{-1}$. B) Magnification of A) to highlight the reduction of nitrate ions.
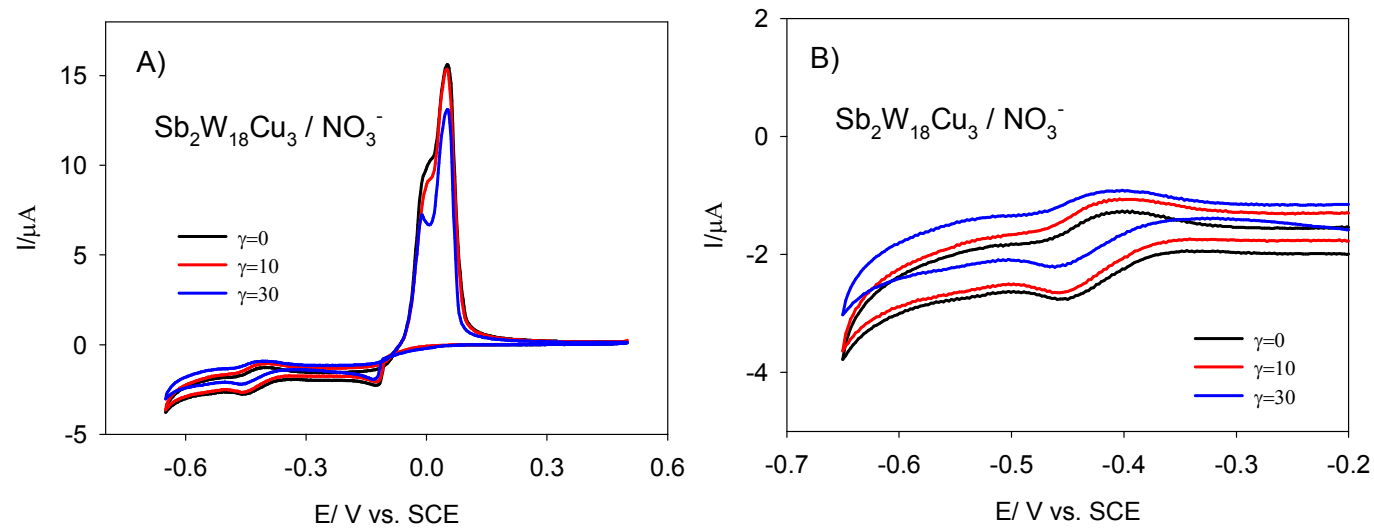

Figure SI20. A) Electrocatalysis of $\mathrm{NO}_{3}$ - reduction in the presence of $0.1 \mathrm{mM} \mathrm{SbW}_{9} \mathrm{CuAle}$ in a pH 1 medium. $\mathrm{v}=2 \mathrm{mV} . \mathrm{s}^{-1}$. B) Magnification of A) to highlight the reduction of nitrate ions.
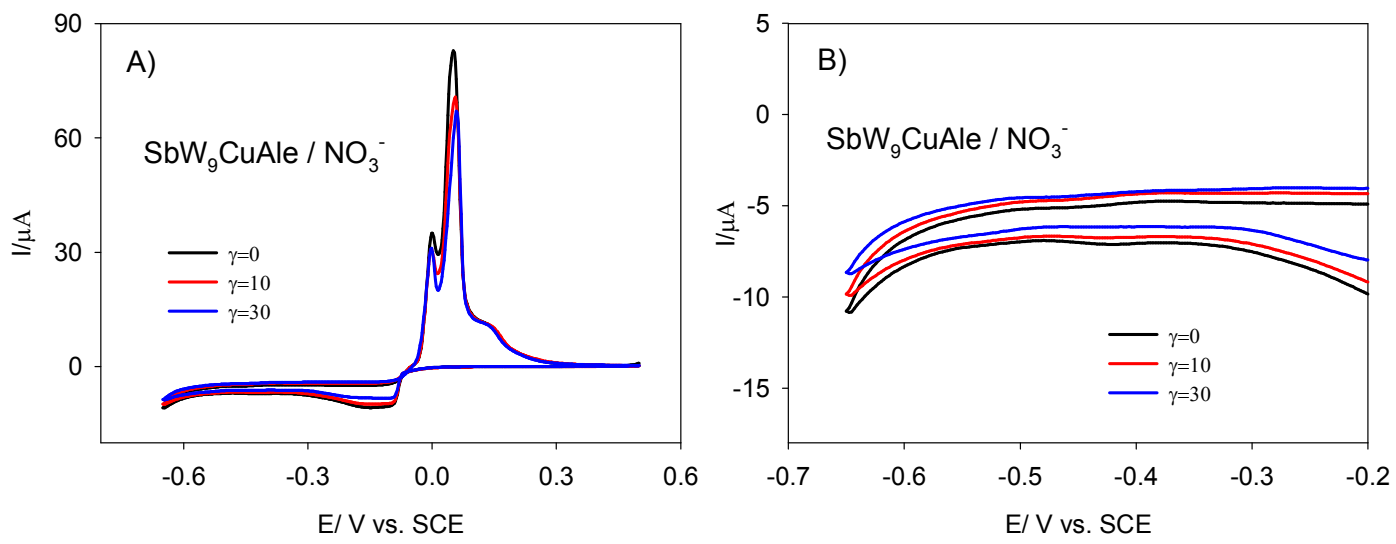
Figure SI21. A) Electrocatalysis of $\mathrm{NO}_{2}{ }^{-}$reduction in the presence of $0.1 \mathrm{mM} \mathbf{S b}_{2} \mathbf{W}_{18} \mathrm{Cu}_{3}$ in a pH 1 medium. $\mathrm{v}=2 \mathrm{mV} . \mathrm{s}^{-1}$. B) Electrocatalysis of $\mathrm{NO}_{2}-$ reduction with reversals potential fixed after the $\mathrm{Cu}^{\mathrm{II}} / \mathrm{Cu}^{\mathrm{I}}$ redox process.
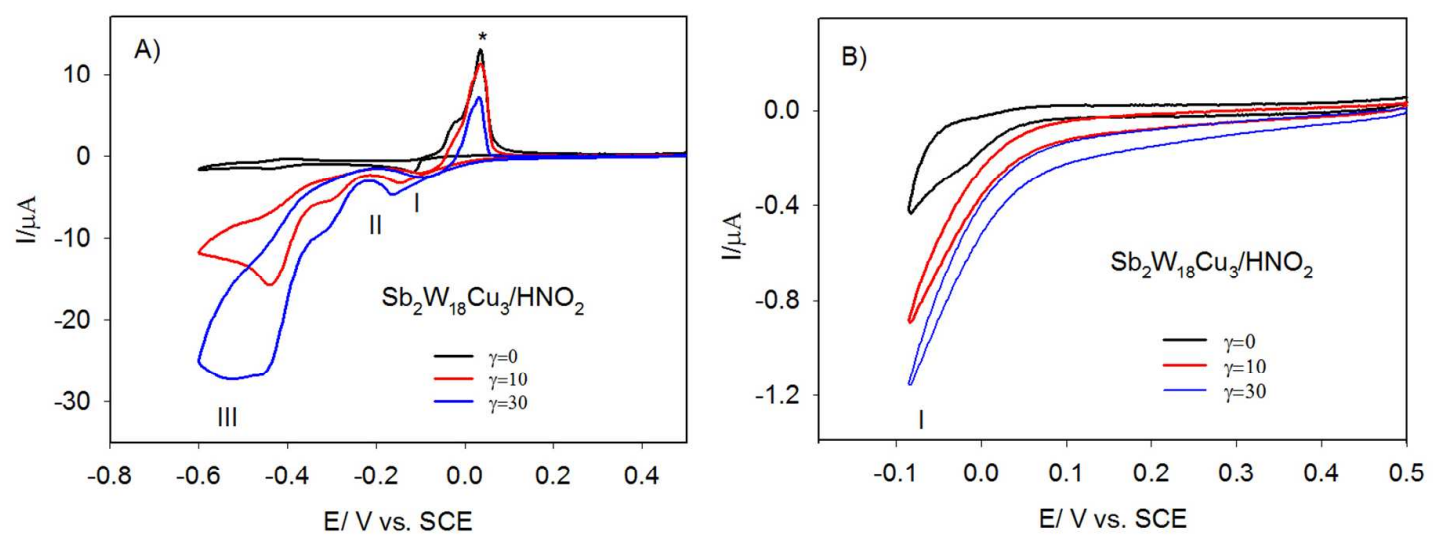

Figure SI22. A) Electrocatalysis of $\mathrm{NO}_{2}^{-}$reduction in the presence of $0.1 \mathrm{mM} \mathrm{Sb_{2 }} \mathbf{W}_{18} \mathrm{Cu}_{3}$ in a pH 5 medium. $\mathrm{v}=2 \mathrm{mV} . \mathrm{s}^{-1}$. B) Electrocatalysis of $\mathrm{NO}_{2}{ }^{-}$reduction with reversals potential fixed after the $\mathrm{Cu}^{\mathrm{II}} / \mathrm{Cu}^{\mathrm{I}}$ redox process.
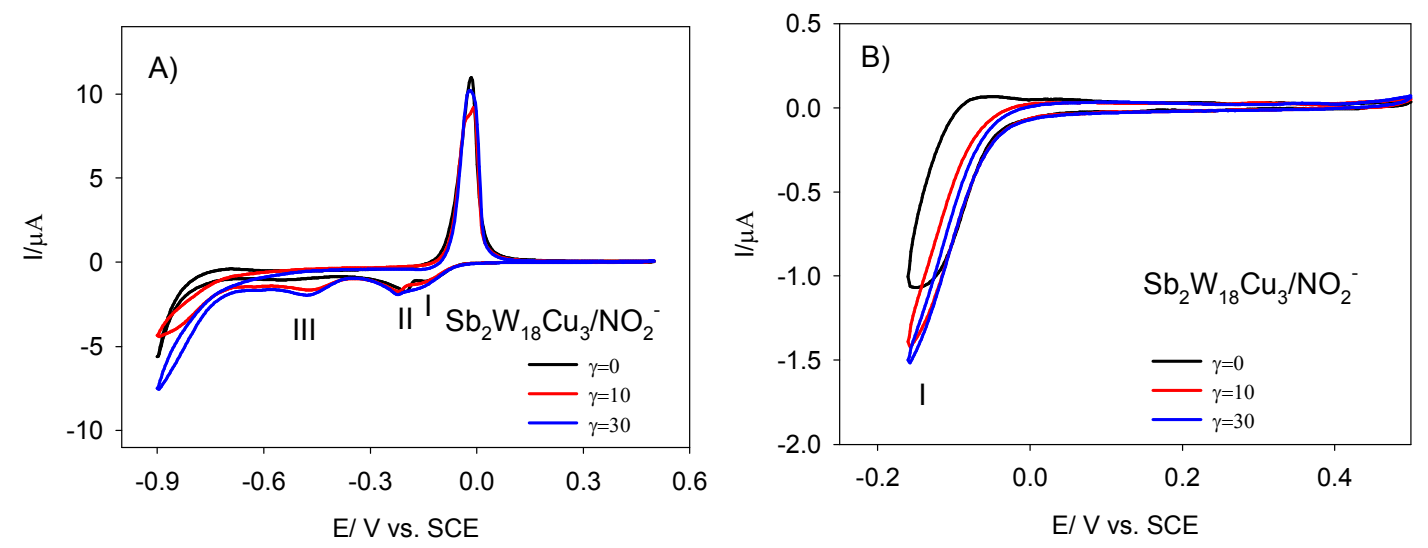
Figure SI23. A) Electrocatalysis of $\mathrm{NO}_{2}-$ reduction in the presence of $0.1 \mathrm{mM} \mathrm{SbW}$.CuAle in a pH 1 medium. $\mathrm{v}=2 \mathrm{mV} . \mathrm{s}^{-1}$. B) Electrocatalysis of $\mathrm{NO}_{2}-$ reduction with reversals potential fixed after the $\mathrm{Cu}^{\mathrm{II}} / \mathrm{Cu}^{\mathrm{I}}$ redox process.
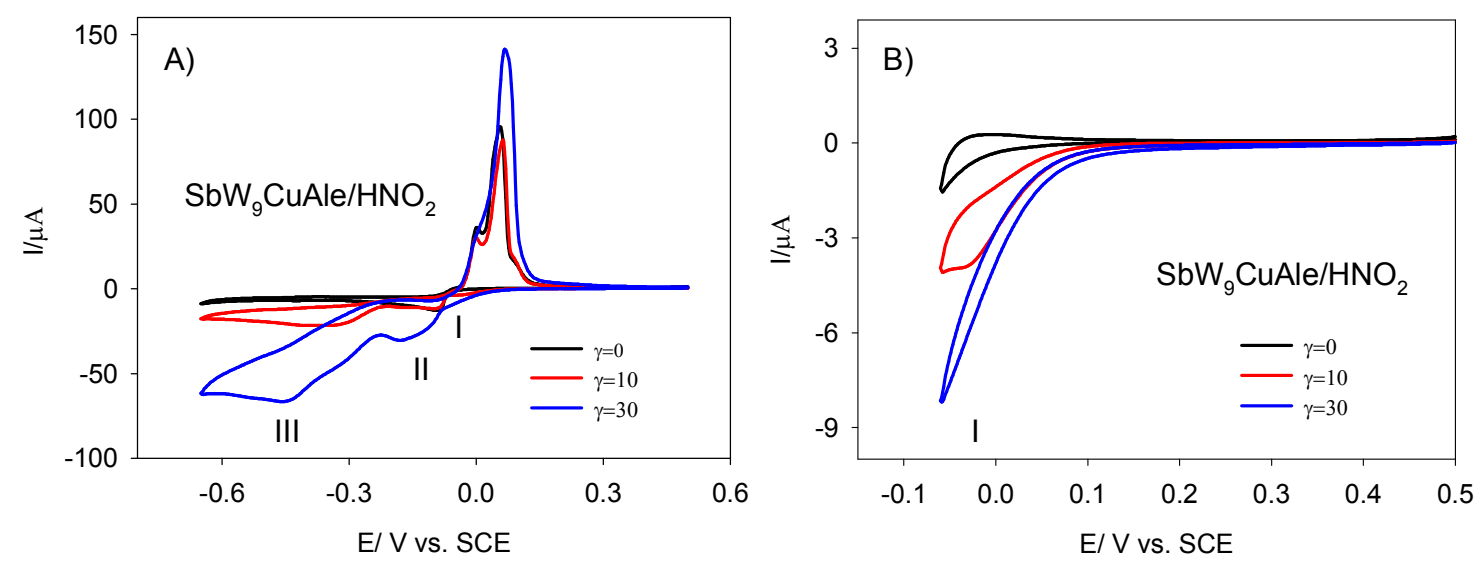

Figure SI24. Electrocatalysis of $\mathrm{NO}_{2}-$ reduction in the presence of $0.1 \mathrm{mM} \mathrm{SbW} \mathbf{m}_{9} \mathrm{CuAle}$ in a pH 5 medium. $\mathrm{v}=2 \mathrm{mV} . \mathrm{s}^{-1}$. B) Electrocatalysis of $\mathrm{NO}_{2}-$ reduction with reversals potential fixed after the $\mathrm{Cu}{ }^{\mathrm{II}} / \mathrm{Cu}^{\mathrm{I}}$ redox process.
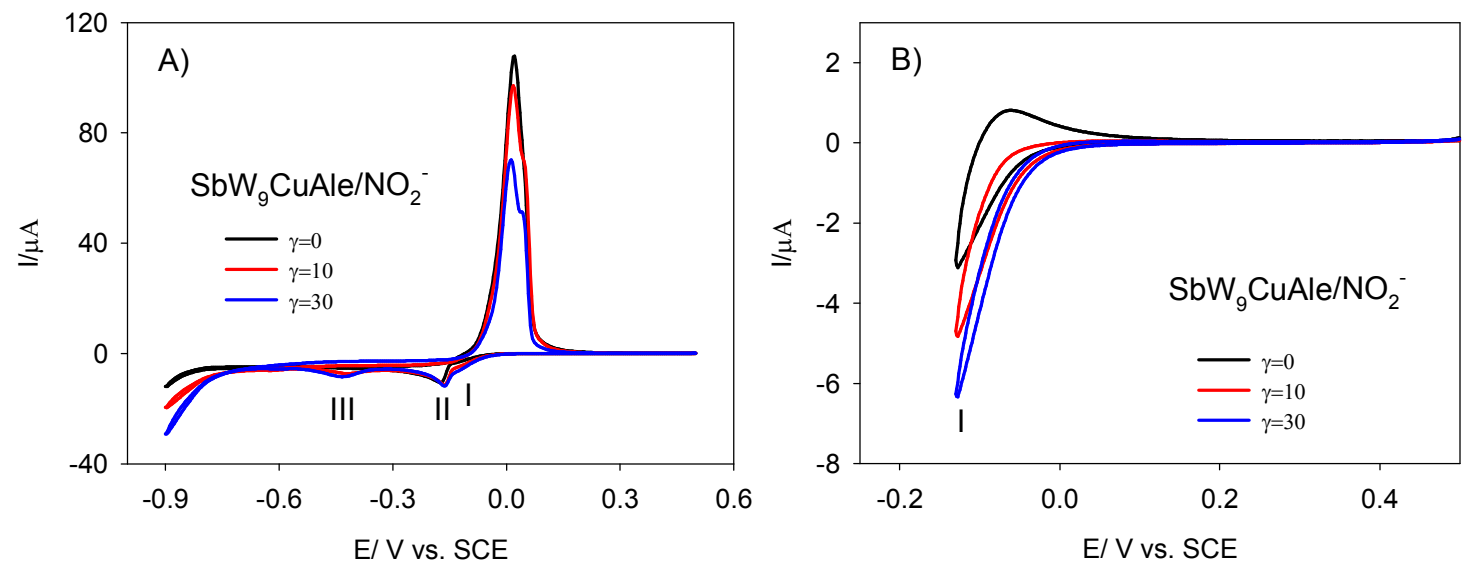
Figure SI25. Electrocatalysis of $\mathrm{NO}_{2}^{-}$reduction in the presence of $0.1 \mathrm{mM} \mathrm{SiW} \mathbf{9} \mathrm{CuAle}$ in a pH 1 medium. $\mathrm{v}=2 \mathrm{mV} . \mathrm{s}^{-1}$. B) Electrocatalysis of $\mathrm{NO}_{2}-$ reduction with reversals potential fixed after the $\mathrm{Cu}^{\mathrm{II}} / \mathrm{Cu}^{\mathrm{I}}$ redox process.
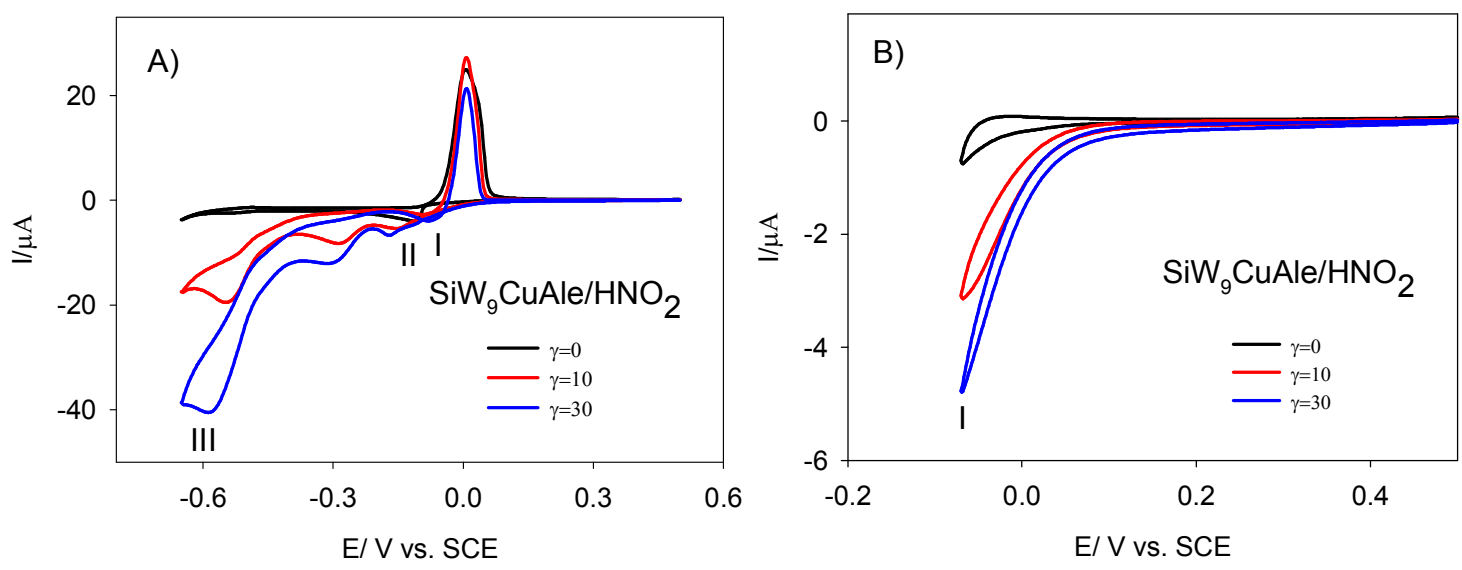

Figure SI26. A) Electrocatalysis of $\mathrm{NO}_{2}-$ reduction in the presence of $0.1 \mathrm{mM} \mathrm{SiW}_{9} \mathrm{CuAle}$ in a pH 5 medium. $\mathrm{v}=2 \mathrm{mV} . \mathrm{s}^{-1}$. B) Electrocatalysis of $\mathrm{NO}_{2}-$ reduction with reversals potential fixed after the $\mathrm{Cu}^{\mathrm{II}} / \mathrm{Cu}^{\mathrm{I}}$ redox process.
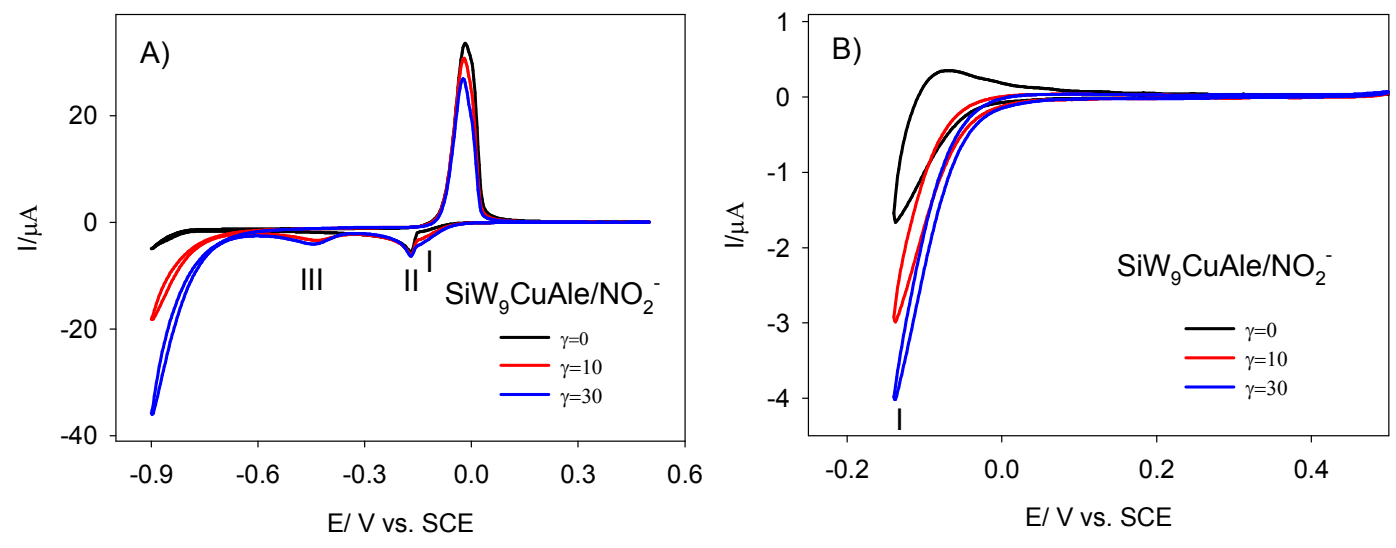
Figure SI27. Electrocatalysis of $\mathrm{NO}_{2}-$ reduction in the presence of $0.1 \mathrm{mM} \mathrm{P}_{\mathbf{2}} \mathbf{W}_{\mathbf{1 5}} \mathbf{C u}_{\mathbf{4}}$ in a pH 5 medium. $\mathrm{v}=2 \mathrm{mV} \cdot \mathrm{s}^{-1}$. B) Electrocatalysis of $\mathrm{NO}_{2}-$ reduction with reversals potential fixed after the $\mathrm{Cu}^{\mathrm{II}} / \mathrm{Cu}^{\mathrm{I}}$ redox process.
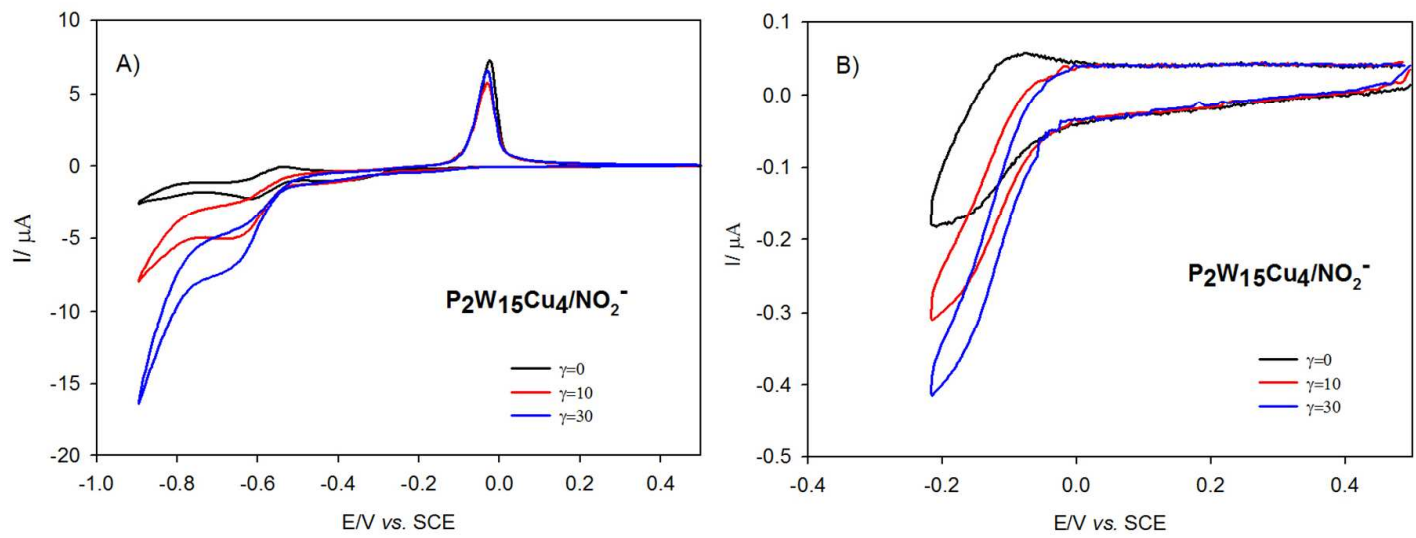

Figure SI28. Electrocatalysis of $\mathrm{NO}_{2}$ - reduction in the presence of $0.1 \mathrm{mM} \mathrm{P}_{\mathbf{2}} \mathbf{W}_{\mathbf{1 5}} \mathrm{Cu}_{\mathbf{4}}$ in a pH 1 medium. $\mathrm{v}=2 \mathrm{mV} \cdot \mathrm{s}^{-1}$. B) Electrocatalysis of $\mathrm{NO}_{2}-$ reduction with reversals potential fixed after the $\mathrm{Cu}^{\mathrm{II}} / \mathrm{Cu}^{\mathrm{I}}$ redox process.
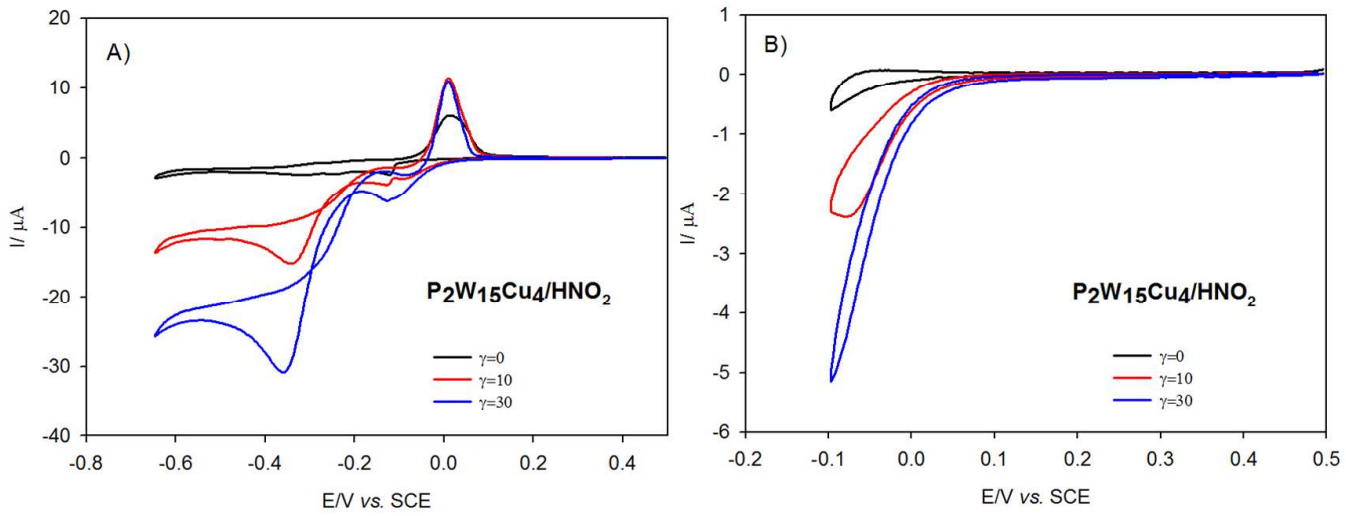